\title{
MATHEMATICAL EDUCATION IN SOUTH ASIA
}

\begin{abstract}
$\mathrm{A}^{\mathrm{N}}$ $\mathrm{N}$ international conference on mathematical education, with special reference to countries of South Asia, was held in Bombay at the Tata Institute of Fundamental Research during February 22-28, under the presidency of Prof. $K$. Chandrasek. haran, of the Tata Institute.

In his presidential address, Prof. Chandrasekharan suggested that difficulties in South Asia stem from an inadequate recognition of the value of creative intellectual activity as part of the drive towards prosperity, and put forward five proposals to enable the creative scientist to come into his own. First, the gifted research worker must be given a suitable working atmosphere and adequate financial support this might be done through a system of research contracts set up by a government and administered by a national committee for mathematics. Secondly, the facilities for training students in advanced mathematics must be increased, by providing graduate schools for advanced study. Thirdly, courses of study must be integrated, and the present very rigid examination system radically modified. Fourthly, the teaching staff in colleges must be reinforced, and the teacher must be given more leisure, more encouragement, and more opportunity for keeping in touch with new ideas in mathematics. Fifthly, suitable text-books must be provided; if need be, a national text-book committee, equipped with adequate funds, must be set up to seek out competent authors and induce them to write the much-needed books. Finally, the school course must be revised and rendered more elastic, since creative mathematics cannot prosper fully unless the foundations are firmly laid in the schools.

Invited addresses were given to the conference by
\end{abstract} Prof. A. D. Alexandrov (U.S.S.R.), Prof. E. Bompiani (Italy), Prof. T. A. A. Broadbent (United Kingdom), Prof. G. Choquet (France), Prof. H. Freudenthal (The Netherlands), Prof. E. Marczewski (Poland), Prof. A. Oppenheim (Malaya), Prof. M. H. Stone (U.S.A.), Prof. Hsio-Fu Tuan (China). Some of these addresses dealt with the problems of mathe. matical education arising in the speaker's country, and described methods which are being used in the solution of such problems. Others dealt with the application of new methods in psychology to mathematical education, with new ideas in teaching arithmetic, and with the best way of beginning the teaching of geometry.

For detailed discussion of special questions, and particularly of the five points raised in the presidential address, members of the conference were divided into three working groups, one for the school stage, one for the bachelor's or master's degree stage, and one for the postgraduate stage. Each group discussed, in its relevant context, the aim of mathematical education, the ideal scope and content of the course, the recruitment, maintenance and training of the teacher, the mode of selection of the students at the higher levels and maintenance of such students, and the necessary facilities and equipment to be required. It was concluded that, at the schools, instruction should be closely related to the needs, the capacity and the interests of the pupil, and an integrated and simplified course, including some statistics as well as the traditional subjects, should be offered. At the universities, the degree course should meet the requirements of society in general, should train those intending to teach mathematics in schools or universities, and should begin the training of the professional mathematician. The postgraduate training should fit students for research and for the teaching of advanced mathematics; here a course of lectures in the most recent developments is essential, though no formal examination should be imposed. Examinations at the lower levels should be more flexible, no student should be asked to stake his whole career on the results of a single examination, written examinations should be supplemented by oral examinations and by an evaluation of the student's total performance; where possible, teachers should participate in the examination of their own students. The provision of text-books, scholarships, summer schools and seminars, and research contracts, was examined in detail, and specific recommendations were made.

The working groups reported interim progress to plenary sessions, from which further instructions were received. Finally, the findings of the working groups were incorporated in a set of resolutions presented to and unanimously adopted by the last plenary session of the conference. This session further resolved to set up a permanent small committee for mathematics in South Asia, under the chairmanship of Prof. Chandrasekharan; this committee would bring the resolutions of the conference to the notice of respensible educational authorities in South Asia, and press for the rapid implementation of these proposals. It is hoped to have on this committee representatives of India, Pakistan, Burma, Ceylon, Indonesia, MalayaSingapore, and Thailand.

No member of the conference could fail to be impressed by the vast problems confronting the teachers of mathematics in South Asia, the urgent needs of the students in those countries, and the enthusiasm of their teachers. Perhaps because of the magnitude of the problems, the conference worked harmoniously, national and sectional interests seldom being allowed to intrude. But above all, the success of the conference was due to the knowledge, skill, organizing ability and driving force of the president, Prof. Chandrasekharan. $\mathrm{He}_{\mathrm{e}}$ focused attention on special problems, induced strong and definite resolutions, and left no doubt in members' minds that great efforts will be made to have these proposals accepted and implemented by the appropriate authorities in the countries of South Asia.

\section{SCIENCE AND PEOPLE}

T $\mathrm{N}$ his presidential address to the American Associa$\mathbf{1}$ tion for the Advancement of Science at Atlanta on December 28, 1955, Dr. Warren Weaver, of the Rockefeller Foundation, examined the influence of science on people (Science, 122, No. 3183).

Science, he said, has impressively proved itself to be a powerful way of dealing with certain aspects of our experience. These are, in general, the logical and quantitative aspects, and the method works superbly for linear and stable physical problems in two or three variables. The physical universe seems to be put together in such a way that this scientific 
approach is exceedingly successful in producing a good, workable, initial description. With that kind of solid start, physical science can then safely proceed to elaborate more sophisticated theories.

How far these methods will be successful in the world of living things is not yet known. The successes to date are very impressive. One feature after another that previously seemed to fall in a special 'vital' category has usefully yielded to biochemical or biophysical attack. As yet only a beginning has been made. How far the logical quantitative method will succeed here, it would be rash to forecast, although the prospects seem extremely promising.

Small beginnings at extending the scientific method into the social sciences have been made. In so far as these fields can be dealt with in terms of measurable quantities, they seem to present closely intercoupled situations that can very seldom usefully be handled with two or three variables and often require very many-for example, W. Leontief's input-output analysis of the United States economy deals with some fifty variables and regrets that it does not handle more. Science has, as yet, no really good way of coping with these multivariable but non-statistical problems, although it is possible that ultra highspeed computers will inspire now sorts of mathematical procedures that will be successful in cases where the effects are too numerous to handle easily but not numerous enough or of suitable character to permit statistical treatment. If we try to avoid the many-variable aspect of the social sciences by using highly simplified models of few variables, then these models ure often too artificial and over-simplified to be useful. The statistical approach, on the other hand, has recently exhibited-for example, in the stochastic models for learning-new potentialities in the field of human behaviour.

It is not at all necessary that the particular analytical techniques of the physical sciences be forced upon biological or social problems with the arrogant assumption that they can and should make unnecessary other types of insight and experience. During the Second World War, an extremely useful collaboration was developed, known often as operations analysis, in which reasoning of a mathematical type was applied to certain aspects of very complicated situations, but with no expectation that judgment, experience, intuition, or a vague sort of general wisdom would be displaced or superseded-rather only that these would be aided by whatever partial light could be furnished by quantitative analysis.

An important characteristic of science is its in capacity to be impractical. The most far-reaching discoveries and the most widespread useful applications flow regularly out of ideas that initially seem abstract and even esoteric.

Science presents the kind of challenge that attracts to it young men and women who tend to have a rather high degree of a certain kind of intelligence. But scientists are not special creatures: they are people. The great majority of scientists have the same distribution of moral and intellectual characteristics as other educated people.

If scientists are human, so also is science itself. For example, science does not deserve the reputation it has so widely gained of being based on absolute fact, of being wholly objective, of being infinitely precise, of being unchangeably permanent, of being philosophically inescapable and unchallengeable. There seem still to be persons who think that science deals with certainty; it deals with probabilities.
The ablest scientists themselves realize the postulational and provisional character of science. Perhaps not so widely recognized or accepted is the extent to which the development of Western science has been influenced by the general nature of Græco-Judaic culture, including especially the standards, arising within that tradition, of what is interesting and important.

The previous comments concerning general characteristics of science suggest that science is a very human enterprise, coloured by general ideas, changeable as any human activity must be, various in its possible forms, and a common part of the lives of all men.

Even the impressive methods that science has developed involve only improvement of procedures of observation and analysis that the human race has always used.

These comments do not support the concept of science as some sort of super creed. This point of view does not justify the notion that science is so special as to be unique, as well as so curious as to be incomprehensible. This does not depict scientists as strange creatures who are in one sense so objective, judicial and precise as to be incredible, and in another sense so apart from life as to be selfish and sinister. This does not set up quantitative analytical Western science as the only valid way in which man may approach and interpret experience.

These descriptive comments picture science as the servant of man, not his master ; and as a friendly companion of art and of moral philosophy.

The lack of general comprehension of science is dangerous both to science and to the public, these being interlocked aspects of the common danger that scientists will not be given the freedom, the understanding and the support that are necessary for vigorous and imaginative development.

\section{TECHNICAL INFORMATION SERVICES IN EUROPE}

TNDER the title "Technical Information Services in Europe", the European Productivity Agency of the Organization for European Economic Cooperation has published a report on the second meeting of technical information officers, held in Frankfurt-am-Main during May 2-6 last (from the Organization, 2 Rue André Pascal, Paris, 16e). The conference, which included delegates from twelve different countries, was intended to give participants an insight into the functioning of the technical information services which are an integral part of the German Productivity Centre at the Rationalisierungskuratorium der Deutschen Wirkschaft in Frankfurt, and the first section of the report outlines the services, activities and relations of this body. It is a private organization which has as its aim the rationalization of the entire German economy and increased productivity, and in this task representa. tives of science and engineering, of industry, and of trade, commerce and crafts, of trade unions and of government agencies are co-operating with it. It is organized both on a regional and on a subject basis and has a priority programme covering those fields where it is believed that an actual increase in productivity can be achieved. In referring to information services, Dr. Magnus, of the board of directors of the Rationalisierungskuratorium, emphasized the im. 